\title{
Typology and Prospects for the Improvement of Market Gardening Systems in South-Kivu, Eastern DR Congo
}

\author{
Serge S. Ndjadi ${ }^{1,2}$, Roger K. Vumilia ${ }^{3}$, Léonard E. Ahoton ${ }^{2}$, Aliou Saidou ${ }^{4}$, Bello D. Orou ${ }^{2}$, \\ Yannick Mugumaarhahama ${ }^{5}$, Léonard M. Kazamwali ${ }^{6}$ \& Gustave N. Mushagalusa ${ }^{1}$ \\ ${ }^{1}$ Department of Crop Science, Faculty of Agriculture and Environmental Studies, Université Evangélique en \\ Afrique, South-Kivu, DR Congo \\ ${ }^{2}$ Plant Biology Laboratory, School of Plant Production Sciences and Techniques, Faculty of Agronomic Sciences, \\ University of Abomey Calavi, Cotonou, Benin \\ ${ }^{3}$ Institut National d'Etudes et de Recherches Agronomiques, Kinshasa, DR Congo \\ ${ }^{4}$ Soil Science Laboratory, School of Plant Production Sciences and Techniques, Faculty of Agronomic Sciences, \\ University of Abomey Calavi, Cotonou, Benin \\ ${ }^{5}$ Unit of Applied Biostatistics, Faculty of Agriculture and Environmental Studies, Université Evangélique en \\ Afrique, South-Kivu, DR Congo \\ ${ }^{6}$ Department of Rural Economy, Faculty of Economics and Management Sciences, Université Evangélique en \\ Afrique, South-Kivu, DR Congo \\ Correspondence: Serge S. Ndjadi, Plant Biology Laboratory, School of Plant Production Sciences and \\ Techniques, Faculty of Agronomic Sciences, University of Abomey Calavi, 01 P.O. Box 526 RP, Cotonou, Benin. \\ Tel: 229-6853-6462. E-mail: ndjadishakanye@gmail.com
}

Received: February 15, 2020

Accepted: April 2, $2020 \quad$ Online Published: May 15, 2020

doi:10.5539/jas.v12n6p136

URL: https://doi.org/10.5539/jas.v12n6p136

\begin{abstract}
Vegetables play a very important role in rural and urban communities as both food and a business opportunity. They are fast-growing species, with high nutritional values and able to generate income in a relatively short period compared to other crops. A characterization of market gardening systems was carried out with 368 producers from major market gardening sites in South-Kivu, in Easten of the RD Congo.The aim pursued was to assess existing systems and perspectives to enable steady transition to integrated, sustainable and resilient crop systems. The results showed that very few producers in the region practice plant integration. The typology carried out made it possible to identify three classes of market gardening farms based on adopted agronomic practices, production factors and possible outcomes derived from different systems. Most of the surveyed farms practice crop rotation and are market-oriented. However, they majorly differ in terms of farm size, practices of intercropping, permanent agriculture, mulching, production constraints and producer's perception on the level of production. For instance, producers who are much more into intercropping also cultivate small areas (less than 0.25 ha). Results also showed that variables such as type of labour, cropping system, type of fertilizer used, mulching practice, adoption of permanent agriculture, producer's perception of the level of soil fertility, and the water source used affect producer's appreciation of the level of production obtained $(p<0.05)$. These variables can be mobilized for improvement of the market gardening system towards more sustainable, diversified and resilient systems.
\end{abstract}

Keywords: agroecology, market gardening, sustainable agriculture, food security, diagnosis

\section{Introduction}

Agriculture remains a growing sector in most of developing countries. With the rapid pace of population growth (Imai et al., 2015), food needs are becoming greater, requiring more commitments from governments and producers (Vanlauwe et al., 2015). In Africa, the agricultural sector provides full-time employment to about $70 \%$ of the population (Jayne, 2014). However, despite this high percentage of farmers, there are areas in some countries where populations are under food insecurity (Mellor, 2014). This is the case for the Democratic Republic of Congo. With more than 80 million hectares of arable land, the country is endowed with unmatched agronomic potential in Africa (MINAGRI, 2013). Nevertheless, the majority of its population remains exposed 
to food insecurity, malnutrition and hunger (James \& Nlemfu, 2016). The same can be said for the Province of South-Kivu, the area of interest of the current study.

The Province of South-Kivu, in particular, is one of the country's Provinces with the highest poverty rate at country level $(84.7 \%$ against $71.3 \%)$ despite a strong agricultural potential. Agriculture remains so far the most important sector within the Province and employs $68.7 \%$ of the active population (Nsimire, 2012; Nfundiko, 2014). For a long time, the Province's agricultural resources have earned it the title of "granary of the country", supplying food and agricultural products to other provinces and neighbouring countries (Ndjadi et al., 2019). This situation emphasizes a great paradox between the gloomy development indicators exhibited by the Province and its agricultural potential, but also a flagrant link between the severity of poverty and food situation (CIALCA, 2010). This situation is mainly due to the low income of the population, which is mainly located in rural areas and living in a precarious environment. Nevertheless, the Province of South-Kivu still offers favourable pedoclimatic conditions for different types of crops, such as market gardening, which is one of the evolving agricultural sectors within the Province.

Market gardening offers opportunities against hunger through production of a varied range of vegetables that can improve the diet and nutritional status of households (Ouédraogo et al., 2019). The related income can also facilitate access to other types of food and vital resources. In the current context of climate change where we are witnessing recurrent cereal deficits, market gardening appears as an interesting alternative in alleviating poverty and food insecurity both in urban and rural areas (Mankoussou et al., 2016).

In view of the urban population growth that leads to a strong demand for market garden products, the market gardening sector constitutes an important source of jobs and food. In South Kivu, 60,000 tons of vegetables are produced each year, creating income to a significant number of small producers (USAID, 2015). Despite this production, the supply balance remains in deficit and insufficient to meet the ever-increasing demand. The gap is therefore filled with imports, deteriorating the terms of trade and with significant effects on the balance of payments (Vwima et al., 2013).

However, the gardening sector in South-Kivu is facing many challenges that are hampering its development. In addition to the low level of control over production factors, market gardening is subject to land insecurity, especially in peri-urban areas. The cultivation of the same speculations by most market gardeners leads not only to a drop in product prices but also to a lack of diversity within the sector of the vegetables. These difficulties are compounded by the lack of an integrated, resilient, efficient and sustainable agro-ecological production system. In addition to this, the instability of prices on the market, the lack of professionalism of the actors, the inability of research institutions to propose scientifically supported orientations are also elements that weaken the market gardening sector within the Province.

In terms of consumer requirements, the quality, quantity and regularity of vegetable supplies remain a challenge for producers who have to respond to heavy demands. To this end, the choice of strategies and orientations towards a more productive, efficient, diversified, sustainable, and resilient production method will necessarily depend on information resulting from a thorough and participatory diagnosis. Such a diagnosis is important for characterizing the intrinsic state of the market gardening sector in terms of technical itineraries and levers that can be mobilized for its improvement. The objective of the present study is therefore to assess the market gardening systems encountered in South-Kivu and the possibilities of a transition towards a sustainable, resilient and efficient agro-ecological system.

\section{Method}

\subsection{Study area}

This study was carried out in the Democratic Republic of Congo, South-Kivu Province, Kabare territoire, $\left(2^{\circ} 22^{\prime} 60^{\prime \prime} \mathrm{S}\right.$ and $\left.28^{\circ} 46^{\prime} 60^{\prime \prime} \mathrm{E}\right)$, located at $28 \mathrm{~km}$ away from Bukavu city on the road to Goma. The landscape of Kabare is of mountainous type, its topography presents three more or less stepped levels. This landscape is part of the western ridge of the Central African Group (Karhagomba et al., 2013). 


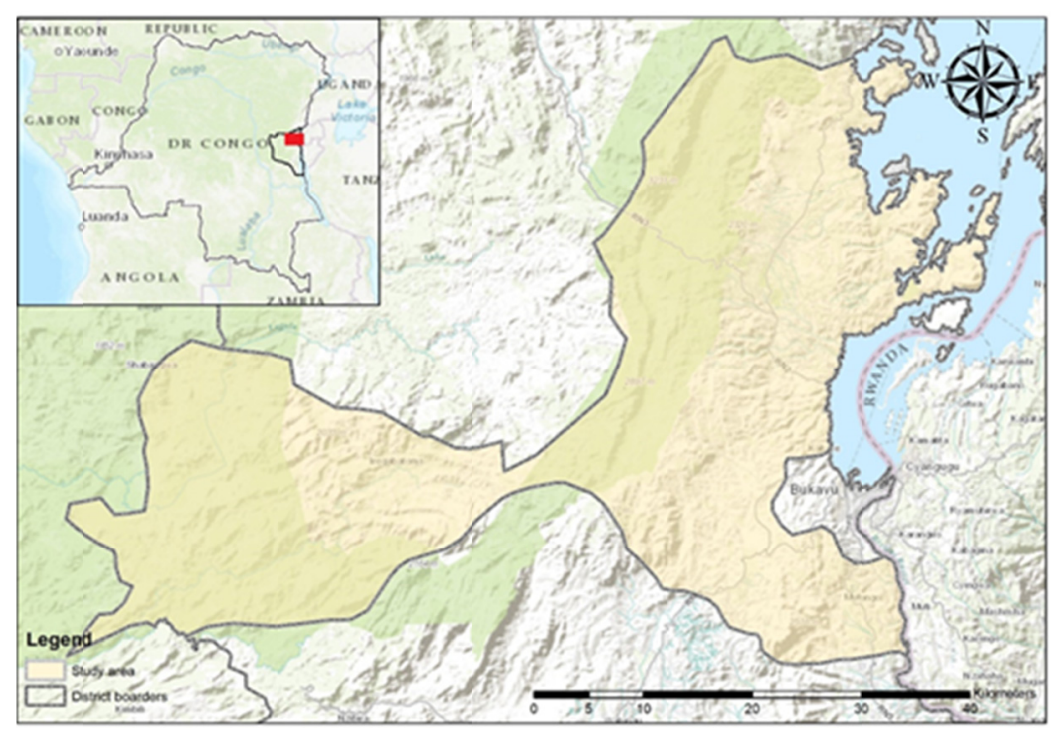

Figure 1. Map of the study area

The climate is of the humid tropical type with a mean annual temperature of $19.9^{\circ} \mathrm{C}$ and a daily amplitude varying between 10 and $20^{\circ} \mathrm{C}$ (Lunze et al., 2012). The rainy season extends from September to May while the dry season takes place from June to August.

The vegetation of the district used to be of a natural tiered type and presented several plant species but no longer exists nowadays due to overexploitation of the soil and scarcity of arable land. Nevertheless, the vegetation is mainly composed of banana plantations, bamboos, some fruit trees and agro-forestry species. Food crops such as maize, pulses, and cassava are also grown. There are also some industrial crops such as coffee, cinchona, tea, and sugar cane. Vegetable crops are also widely grown in this region.

As for soil, this one is of volcanic type and contains a lot of humus, including the basaltic soils mostly found in the southern part of Lake Kivu. Alluvial soils occupy valley bottoms and are potentially fertile (Pypers et al., 2011). The region also has several wetlands where food crops and typical market gardening are grown annually.

\subsection{Sampling, Data Collection, and Analytical Methods}

The proportion of surveyed producers was obtained using the normal approximation of the binomial distribution based on Dagnelie (1998) used by Balogoun et al. (2014).

$$
\mathrm{N}=\frac{\mathrm{P}_{\mathrm{i}}\left(1-\mathrm{P}_{\mathrm{i}}\right) \times \mathrm{U}_{1-\frac{\alpha}{2}}^{2}}{\mathrm{~d}^{2}}
$$

Where, N: sample size; Pi: the proportion of market gardening households; $\mathrm{U}_{1-\alpha 2}^{2}$ : the value of the normal random variable is 3.8416 for a probability equal to 0.975 and d: the expected margin of error evaluated at $5 \%$. Based on the p-values from the results of the exploratory phase, 368 producers were selected. Several groupements such as Mudaka, Bushwira, Miti, Bugorhe, and Irhambi-Katana were selected based on the intensity of market gardening activities, their proximity to the city of Bukavu. Using a stratified random approach, we selected 90 persons in Mudaka, 66 in Bushwira, 78 in Miti, 70 in Bugorhe, and 64 in Irhambi-Katana.

A single individual survey followed by focus groups was conducted from 15 June to 30 September 2018. Using a structured survey questionnaire, the information collected covered socio-demographic characteristics of households (household size, number of agricultural workers, main activities and other activities carried out, age of the household head, gender, level of education, experience in agriculture and market gardening, membership to a farmer organization, etc.).

The characteristics of agricultural holdings (exploited area, cropping system adopted, speculations exploited, perception of the level of soil fertility, type of fertilisers used, practice of permanent agriculture, water source, type of labour employed, practice of moisture conservation, etc.). 
Some additional information collected from the surveyed households concerned the type of cropping systems adopted by farmers and farmers' appreciation towards production level. Such assessment is very critical since it expresses the producer's level of judgement regarding the output achieved.

\subsection{Statistical Analysis of the Data}

The statistical analyses consisted mainly of multivariate factor analysis using the FactoMineR library (Lê et al., 2008) of the R software in its version 3.5.1 (R Development Core Team, 2018). Multivariate factor analysis is part of data reduction techniques that aim at capturing the variance in the variables within a data set. It is most of the time confused with principal component analysis, another popular technique of multivariate analysis with much more similar outputs and identical goal (capturing the variance in the variables). Despite the similarities between the two models, they are fundamentally different. Principal component analysis is more of a linear combination technique, whereas factor analysis stands as a model of measurement of a latent variable. The latter cannot be directly measured through one variable but several output or indicator variables. All candidate variables used for this analysis were qualitative. Therefore, a multiple correspondence factor analysis was performed using the Multiple Correspondence Analysis (MCA) procedure. The coordinates of the individuals on the first five main axes (accumulating $51.24 \%$ of the total inertia) were retained. They were used for hierarchical upward classification into Hierarchical Clustering Principal Components (HCPC). An ordinal logistic regression was conducted to determine factors influencing production appreciation using the polr procedure of the MASS library (Venables \& Ripley, 2002) in R.

Production appreciation, seen as a utility maximization problem, can be modeled using a choice experiment approach. As suggested by Lancaster's model of consumer choice, consumers derive their satisfaction from both goods and attributes they provide. Borrowing from Birol and Smale (2006), let us assume that a farmer has to choose from a set of different market gardening systems (called C) susceptible to yield different levels of production based on the input combination they require or the constraints they impose. Farmer's ultility with regard to the available alternatives will therefore be a function different factors that can be summuraized by the following mathematical relationship:

$$
\mathrm{U}_{\mathrm{ij}}=\mathrm{V} \cdot\left(\mathrm{Z}_{\mathrm{j}}, \mathrm{Si}\right)+\mathrm{e}\left(\mathrm{Z}_{\mathrm{j}}, \mathrm{S}_{\mathrm{i}}\right)
$$

Where, $i$ refers to a given farmer facing any market gardening system $j$ associated with a certain level of utility. In that context, the utility derived from different market gardening systems partially depends on the goods or level of production that can be obtained from them $(Z)$ as well as farmer's social and economic characteristics (S). Therefore, farmer's level of appreciation of production asscociated with different market gardening systems can be seen as a function of the probability that the utility derived from a given system is higher or lower as compared to that of other systems. Considering that ranking, the probability that a farmer's level of appreciation falls in a given category can be expressed in terms of an ordinal logistic regression. However, since the dependent variable is unobservable (because we are dealing with sentiments), this model is not a regression model. It is instead called an index model. The ranking made by farmers based on the choice they make is relative to certain thresholds. Since farmers have to express their appreciation towards the level of production derived from a given gardening system as "low", "medium" and "high", we have three outcomes $M=3$ but $M-$ $1=2$ thresholds $\mu_{1}$ and $\mu_{2}$, with $\mu_{1}<\mu_{2}$. This index model does not have an interpect to avoid any multicollinearity problem with the threshold variables. If the farmer presumes that production in a given market gardening system is not satisfactory, then his sentiment in terms of production appreciation will fall under the lowest category, and so then $\mathrm{y}_{\mathrm{i}}{ }^{*} \leq \mu_{1}$ and the alternative "low" will be chosen; if $\mu_{1}<\mathrm{yi}^{*} \leq \mu_{2}$ then the alternative "medium" is chosen, and if he presumes that the level of production derived from the exploited market gardening system is high, i.e., $\mathrm{y}_{\mathrm{i}}^{*}>\mu_{2}$, and category is "high" is chosen.

The comparison of the modalities of a variable, taken in pairs, was done using the emmeans and cld procedures of the emmeanset multcomp libraries (Hothorn, et al., 2008) respectively.

\section{Resultas}

\subsection{Description of Socio-demographic Characteristics of Producers by Groupement}

Socio demographic characteristics of producers are presented on Table 1. 
Table 1. Description of socio-demographic characteristics of producers according to the groupements

\begin{tabular}{|c|c|c|c|c|c|}
\hline \multirow[b]{2}{*}{ Variables/Modalities } & \multicolumn{5}{|c|}{ groupements } \\
\hline & $\begin{array}{l}\text { Mudaka } \\
\mathrm{N}=90\end{array}$ & $\begin{array}{l}\text { Bushwira } \\
N=66\end{array}$ & $\begin{array}{l}\text { Miti } \\
N=78\end{array}$ & $\begin{array}{l}\text { Bugorhe } \\
\mathrm{N}=70\end{array}$ & $\begin{array}{l}\text { Katana } \\
N=64\end{array}$ \\
\hline \multicolumn{6}{|l|}{ Sex } \\
\hline Male & $34.4(31)$ & $51.52(34)$ & $41.02(32)$ & $47.15(33)$ & $28.13(18)$ \\
\hline Female & $65.6(59)$ & $48.48(32)$ & $58.98(46)$ & $52.85(37)$ & $71.87(46)$ \\
\hline \multicolumn{6}{|l|}{ Age } \\
\hline Less than 30 & $37.95(34)$ & $40.25(27)$ & $32.16(25)$ & $38.44(27)$ & $35.27(23)$ \\
\hline $30-50$ & $54.12(49)$ & $52.05(34)$ & $58.23(45)$ & $53.32(37)$ & $53.12(34)$ \\
\hline Greater than 50 & $7.93(7)$ & $7.70(5)$ & $9.61(7)$ & $8.24(6)$ & $11.61(7)$ \\
\hline \multicolumn{6}{|l|}{ Household size } \\
\hline 3 to 7 & $75.12(68)$ & $72.85(48)$ & $81.18(63)$ & $85.32(60)$ & $78.25(50)$ \\
\hline Greater than 7 & $24.88(15)$ & $27.15(18)$ & $18.82(15)$ & $14.77(10)$ & $21.75(14)$ \\
\hline \multicolumn{6}{|l|}{ Marital status } \\
\hline Single & $11.11(10)$ & $6.67(4)$ & $15.3(12)$ & $11.43(8)$ & $10.94(7)$ \\
\hline Divorced & $11.11(10)$ & $12.12(8)$ & $12.8(10)$ & $17.14(12)$ & $20.31(13)$ \\
\hline Mariried & $61.11(55)$ & $66.06(44)$ & $61.64(48)$ & $64.29(45)$ & $59.37(38)$ \\
\hline Widower & $16.67(15)$ & $15.15(10)$ & $10.26(8)$ & $7.14(5)$ & $9.38(6)$ \\
\hline \multicolumn{6}{|l|}{ Main activity } \\
\hline Vegetable farming & $61.11(55)$ & $63(42)$ & $76.92(60)$ & $74.29(52)$ & $67.19(43)$ \\
\hline Other crops & $22.22(20)$ & $18(12)$ & $10.26(8)$ & $18.57(13)$ & $20.31(13)$ \\
\hline Small trades & $16.67(15)$ & $18.06(12)$ & $12.82(7)$ & $7.14(5)$ & $12.5(8)$ \\
\hline \multicolumn{6}{|l|}{ Land access method } \\
\hline Heritage & $40.75(18)$ & $19.03(12)$ & $30.37(24)$ & $34.64(24)$ & $28.76(18)$ \\
\hline Purchase & $55.25(20)$ & $50.32(33)$ & $47.28(37)$ & $45.95(32)$ & $59.32(38)$ \\
\hline Rental & $25.75(53)$ & $30.65(20)$ & $22.35(17)$ & $19.41(14)$ & $11.92(8)$ \\
\hline \multicolumn{6}{|c|}{ Membership in an association } \\
\hline Yes & $34.64(31)$ & $28.32(19)$ & $32.20(25)$ & $38.65(27)$ & $25.08(16)$ \\
\hline No & $65.36(59)$ & $71.68(47)$ & $67.80(53)$ & $61.35(43)$ & $74.92(48)$ \\
\hline
\end{tabular}

Table 1 shows that most of the market gardeners in the different groupements are female except in Bushwira where male farmers are slightly dominant than their female counterparts. The majority of producers have between 30 and 50 years of age. This is particularly observed in Miti groupement where $58.98 \%$ of the surveyed farmers fall under that category of age and with only few being over 50 years old. Results in Katana on the other side show more producers beyond the age of $50(11.61 \%)$ as compared to others groupements. Households with a size of 3 to 7 people remain dominant in all study sites. Results in Table 1 show more households with low dependency ratios in groupements like Bugorhe where few of them have more than 7 children (14.77\%).

In all the surveyed groupements, market gardening remains the main activity of producers (at $60 \%$ ), followed by "others crops and small businesses". As for land acquisition, results showed that most of producers have purchased the land they are exploiting (more than $45 \%$ ). Others acquire land by inheritance or by renting, expect in Buswhira where renting (30.65\%) is more dominant than accessing land by inheritance (19.03\%). The survey results also indicate that membership to farmers' organisations is less common among market gardeners. Nevertheless, in Bugorhe the number of market gardeners who are members of associations is high $(38.65 \%)$.

\subsection{Educational Background, Technical and Economic Characteristics of Producers}

Educational background, technical and economic characteristics of producers are presented on Table 2. 
Table 2. Educational background, technical and economic characteristics of producers

\begin{tabular}{|c|c|c|c|c|c|}
\hline \multirow[b]{2}{*}{ Variables $=$ Modalities } & \multicolumn{5}{|c|}{ Groupements } \\
\hline & $\begin{array}{l}\text { Mudaka } \\
\mathbf{N}=90\end{array}$ & $\begin{array}{l}\text { Bushwira } \\
N=66\end{array}$ & $\begin{array}{l}\text { Miti } \\
N=78\end{array}$ & $\begin{array}{l}\text { Bugorhe } \\
\mathrm{N}=70\end{array}$ & $\begin{array}{l}\text { Katana } \\
N=64\end{array}$ \\
\hline \multicolumn{6}{|l|}{ Education level } \\
\hline Illiterate & $44.44(40)$ & $45.45(30)$ & $44.87(35)$ & $57.14(40)$ & $48.24(31)$ \\
\hline Primary school & $24.45(22)$ & $36.37(24)$ & $34.61(27)$ & $14.28(10)$ & $31.25(20)$ \\
\hline Secondary school & $31.11(28)$ & $18.18(12)$ & $12(9)$ & $22.87(16)$ & $12.82(8)$ \\
\hline University & $6.66(6)$ & $9.09(6)$ & $8.52(7)$ & $5.71(4)$ & $7.69(5)$ \\
\hline \multicolumn{6}{|l|}{ Type of labour } \\
\hline Family & $50.00(45)$ & $48.48(32)$ & $51.28(40)$ & $60.00(42)$ & $46.88(30)$ \\
\hline Employee & $22.22(20)$ & $27.27(18)$ & $26.92(21)$ & $25.71(18)$ & $37.50(24)$ \\
\hline Community & $11.11(10)$ & $9.09(6)$ & $6.41(5)$ & $2.86(2)$ & $6.25(4)$ \\
\hline Family and employee & $5.56(5)$ & $15.15(10)$ & $15.38(12)$ & $11.43(8)$ & $9.38(6)$ \\
\hline \multicolumn{6}{|l|}{ Use of the Harvest } \\
\hline Sale & $88.00(79)$ & $85.00(56)$ & $90.00(70)$ & $79.00(55)$ & $95.00(61)$ \\
\hline Consumption & $12.00(11)$ & $15.00(10)$ & $10.00(8)$ & $11.00(8)$ & $5.00(3)$ \\
\hline \multicolumn{6}{|l|}{ Seniority in Other Crops } \\
\hline $3-5$ years & $31.18(15)$ & $25.82(17)$ & $19.84(15)$ & $29.75(21)$ & $18.77(12)$ \\
\hline$>5$ years & $68.82(63)$ & $74.18(49)$ & $80.16(63)$ & $70.25(49)$ & $81.23(52)$ \\
\hline \multicolumn{6}{|c|}{ Seniority in market gardening } \\
\hline 3-5 years & $36.10(24)$ & $32.05(21)$ & $30.93(24)$ & $39.11(27)$ & $35.18(23)$ \\
\hline$>5$ years & $63.90(54)$ & $67.95(45)$ & $69.07(54)$ & $60.89(43)$ & $64.82(41)$ \\
\hline \multicolumn{6}{|l|}{ Available area } \\
\hline$<0,25$ ha & $24.44(22)$ & $19.66(13)$ & $28.20(22)$ & $25.71(18)$ & $15.62(10)$ \\
\hline $0.25-0.99$ ha & $61.11(55)$ & $56.06(37)$ & $55.12(43)$ & $57.14(40)$ & $59.37(38)$ \\
\hline$>1$ ha & $14.44(13)$ & $24.24(16)$ & $16.66(13)$ & $17.14(12)$ & $25.00(16)$ \\
\hline \multicolumn{6}{|l|}{ Area of market gardening } \\
\hline$<0.25$ ha & $19.83(37)$ & $37.18(25)$ & $32.32(24)$ & $11.56(8)$ & $15.65(10)$ \\
\hline $0.25-0.99$ ha & $80.17(53)$ & $78.12(41)$ & $82.35(53)$ & $85.05(60)$ & $88.25(56)$ \\
\hline$\geq 1$ ha & - & - & - & $3.39(2)$ & - \\
\hline
\end{tabular}

Results on educational background, technical and economic characteristics of producers in different groupements show that most market gardeners never attended school. Some of them at least have completed primary or secondary school though in small proportions (see Table 2). Farmers with a university background represent a very small percentage. Regarding labour and the type of labour used, results show that farmers depend more on family labour. Farmers also use two more types of labour, namely hired labour and community labour which is very common in Sub-Saharan Africa. As for the goal of market gardening, reported results show that most of the harvested produce is market-oriented. Crop diversification is also a common practice among farmers, who according to the results have spent more than five years growing "other crops" apart from market gardening. The same trend can also be observed among farmers specialized in market gardening though less prominent compared to those growing other crops.

Results in Table 2 show that farm size in the surveyed areas varies between 0.25 and 0.99 ha. However, in Mudaka, the proportion of producers with plots smaller than 0.25 ha is high compared to those with plots larger than 1 ha (Table 2). A similar situation can also be observed in Miti and Bugorhe. As for Bushwira and Katana, these two groupements exhibit a high number of farmers with larger plots (1 ha on average). Those with small plots (less than $0.25 \mathrm{ha}$ ) are particularly few. With regard to the area allocated to market gardening, results show that these activities are carried on surfaces ranging from 0.25 to 0.99 ha. Other farmers, as shown by the obtained results, have less than 0.25 ha dedicated to market gardening. In broad, market gardening is carried out on areas estimated at less than one hectare, except in Bugorhe where results had shown a small proportion of farmers (3.39\%) who had dedicated more than one hectare to it (see Table 2).

\subsection{Diversity of Market Garden Farms in the Study Area}

The ascending hierarchical classification grouped these farms into three main classes. Discriminant significance is little observed with variables such as sowing mode, group membership, water source, and producers' 
perception of soil fertility, as they are less far from the main axis. While for other variables like cropping system, purpose of cropping system, type of labour used, major constraint, land tenure, available area, harvest use, main activity, area allocated to market gardening, practice of permanent agriculture, use of chemicals and phytosanitary products, type of fertilisers used, mulching practice, as well as the producers' appreciation of the production obtained, make it possible to strongly discriminate between the different classes generated.

3.4 Description of Three Main Types of Market Garden Farms Encountered in the Study Area

3.4.1 Socio-economic and Demographic Characteristics of Market Garden Farmers in the Study Area According to Classes

Socio-economic and demographic characteristics of farmer's class are presents in Table 3.

Table 3. Socio-economic and demographic characteristics of market garden farms

\begin{tabular}{|c|c|c|c|c|c|c|}
\hline \multirow{2}{*}{ Variables $=$ Modalities } & \multicolumn{2}{|c|}{ Type I (14.40\%) } & \multicolumn{2}{|c|}{ Type II (72.83\%) } & \multicolumn{2}{|c|}{ Typee III (12.77\%) } \\
\hline & Frequency & v.test & Frequency & v.test & Frequency & v.test \\
\hline \multicolumn{7}{|l|}{ Land access method } \\
\hline Purchase & 100 & 15.18 & 57.08 & 7.46 & 31.91 & -2.01 \\
\hline Heritage & 0.00 & -6.96 & 40.29 & 2.55 & 55.31 & 2.80 \\
\hline Rental & 0.00 & -8.20 & 2.61 & -11.97 & 12.76 & -0.96 \\
\hline \multicolumn{7}{|l|}{ Type of labour } \\
\hline Family and employee & 92.45 & 15.62 & 0.00 & -12.15 & 2.12 & -2.71 \\
\hline Employee & 1.88 & -5.21 & 33.95 & 4.59 & 21.27 & -1.04 \\
\hline Family & 0.00 & -918 & 59.70 & 4.38 & 72.34 & 2.89 \\
\hline Community & 5.66 & -0.04 & 6.34 & 0.44 & 4.25 & -0.45 \\
\hline \multicolumn{7}{|l|}{ Main activity } \\
\hline Small trades & 53.47 & 11.13 & 0.00 & -8.80 & 0.00 & -2.40 \\
\hline Vegetable farming & 45.28 & -1.88 & 61.19 & 2.42 & 51.06 & 2.43 \\
\hline Other crops & 0.00 & -6.74 & 38.80 & 2.67 & 48.93 & -1.49 \\
\hline \multicolumn{7}{|l|}{ Use of harvest } \\
\hline Consumption & 20.75 & -13.11 & 27.00 & -10.02 & 2.12 & -2.57 \\
\hline Sale & 79.24 & 13.11 & 73.00 & 10.02 & 97.87 & 2.57 \\
\hline \multicolumn{7}{|l|}{ Groupement } \\
\hline Mudaka & 28.30 & 0.70 & 24.25 & -0.15 & 21.27 & 0.51 \\
\hline Bushwira & 18.96 & 0.21 & 17.16 & -0.63 & 21.27 & 0.64 \\
\hline Miti & 20.75 & -0.05 & 21.64 & 0.32 & 19.14 & -0.33 \\
\hline Bugorhe & 18.86 & -0.003 & 19.77 & 0.58 & 14.89 & -0.74 \\
\hline Katana & 13.20 & -084 & 17.16 & -020 & 23.40 & 1.13 \\
\hline \multicolumn{7}{|l|}{ Available area } \\
\hline Less than 0.25 ha & 1.88 & -5.21 & 29.85 & 2.52 & 36.17 & 1.58 \\
\hline $0.25-0.50$ ha & 0.00 & -6.24 & 25.82 & 3.12 & 38.29 & 1.14 \\
\hline $0.50-1$ ha & $0 ; 00$ & -4.70 & 30.22 & 4.71 & 14.89 & -1.60 \\
\hline Greater than 1 ha & 98.11 & 14.51 & 4.10 & -11.03 & 10.63 & -1.49 \\
\hline
\end{tabular}

The results of socio-economic and demographic characteristics of the market garden farms in the study area helped identifying three social classes (see Table 3). Type I exhibits some characteristics that need to be pointed out. Farmers with relatively high living standards own most of farms within this cluster. Moreover, farmers under this cluster own plots they are exploiting and had acquired them through purchasing. As for the land size owned by farmers within the cluster, results show that most of them own large plots, measuring more than one hectare, they use more hired labour and venture into small businesses. Most of farms located in Mudaka and Bushwira belong to this cluster.

Type II farms constitute a middle class between the first and the third clusters. Most of farms within this cluster are acquired by inheritance $(40.29 \%)$ and others are rented $(57.08 \%)$; they make use of three types of labour, namely hired labour (33.95\%), family labour (59.70\%) and community labour (6.34\%). Market gardening stands as the main activity (61.19\%) of farmers, followed by "other crops" (38.80\%). The farm size varies between 0.25 and 1 hectare. Most of farms of Miti and Bugorhe fall under this category. 
Type III farms can be considered as the poor farmer's class. Most of plots exploited by farmers within this class have been acquired by inheritance $(55.31 \%)$ and as for labour and farmers' main occupation; family labour (72.34\%) and market gardening (51.06\%) appear as the most predominant labour type and occupation of producers within this class. Mudaka and Bushwira farms are the ones constituting this cluster.

3.4.2 Characteristics Related to Cropping Systems

Table 4 shows the characteristics relates to the cropping systems at Kabare. 
Table 4. Characteristics related to the cropping systems of Kabare vegetable farms

\begin{tabular}{|c|c|c|c|c|c|c|}
\hline \multirow{2}{*}{ Variables $=$ Modalities } & \multicolumn{2}{|c|}{ Type I (14.40\%) } & \multicolumn{2}{|c|}{ Type II (72.83\%) } & \multicolumn{2}{|c|}{ Typee III (12.77\%) } \\
\hline & Frequency & v.test & Frequency & v.test & Frequency & v.test \\
\hline \multicolumn{7}{|l|}{ Market gardening area } \\
\hline Less than 0.25 ha & 1.88 & -7.68 & 50.37 & 2.97 & 68.08 & 3.27 \\
\hline $0.25-0.50$ ha & 7.54 & -3.39 & 33.20 & 3.12 & 27.65 & -0.16 \\
\hline $0.50-1.00$ ha & 60.37 & 6.86 & 16.04 & -3.61 & 4.25 & -3.31 \\
\hline Greater than 1 ha & 30.18 & -7.51 & 0.37 & -5.85 & 0.00 & -1.68 \\
\hline \multicolumn{7}{|l|}{ Mulching } \\
\hline Yes & 39.62 & 4.03 & 24.25 & -6.96 & 68.08 & 4.90 \\
\hline No & 60.37 & -4.03 & 75.74 & 6.96 & 31.91 & -4.90 \\
\hline \multicolumn{7}{|l|}{ Permanentagricultural system } \\
\hline Yes & 1.89 & -3.83 & 10.82 & -5.85 & 80.85 & 10.24 \\
\hline No & 98.11 & 3.92 & 89.17 & 5.85 & 19.14 & -10.24 \\
\hline \multicolumn{7}{|l|}{ Cropping system practised } \\
\hline Pure crops & 100.00 & 3.54 & 100 & 11.70 & 2.68. & -16.41 \\
\hline Crops mixing & 0.00 & -3.54 & 0.00 & -11.70 & 97.32 & 16.41 \\
\hline \multicolumn{7}{|l|}{ Type of fertilisers } \\
\hline None & 47.16 & 3.15 & 23.88 & -2.97 & 31.91 & 0.59 \\
\hline Mineral & 20.75 & -2.26 & 41.41 & 4.92 & 8.51 & -4.27 \\
\hline Compost & 0.00 & -2.04 & 4.10 & -1.73 & 19.14 & 3.63 \\
\hline Plant debris & 0.00 & -2.43 & 4.47 & -2.94 & 29.78 & 5.24 \\
\hline Animal faeces & 32.07 & 1.25 & 26.11 & 0.80 & 10.63 & 2.54 \\
\hline \multicolumn{7}{|l|}{ Use of phytosanitary products } \\
\hline Yes & 92.45 & -2.56 & 88.0 & 5.89 & 21.27 & -9.53 \\
\hline No & 7.54 & 2.56 & 11.94 & -5.89 & 78.72 & 9.53 \\
\hline \multicolumn{7}{|l|}{ Production appreciation } \\
\hline Low & 39.62 & -0.25 & 47.38 & 3.92 & 8.51 & -5.23 \\
\hline Medium & 50.95 & 2.45 & 32.46 & -2.02 & 36.17 & 0.09 \\
\hline High & 9.43 & -2.68 & 20.14 & -2.14 & 55.31 & 5.13 \\
\hline \multicolumn{7}{|l|}{ Perception of field fertility } \\
\hline Low & 26.41 & -1.49 & 7.08 & -8.83 & 76.59 & 9.46 \\
\hline Medium & 15.09 & 2.69 & 86.1 & 8.25 & 23.40 & -7.85 \\
\hline High & 58.49 & 2.20 & 6.71 & -0.43 & 0.00 & -2.24 \\
\hline \multicolumn{7}{|l|}{ Goal of the cropping system } \\
\hline Rationalizing the use of space & 0.00 & -1.97 & 0.00 & -6.91 & 40.42 & 8.99 \\
\hline Crop harvest Diversification & 0.00 & -2.55 & 0.00 & -8.62 & 59.57 & 11.33 \\
\hline Ease of work & 39.62 & 0.08 & 45.89 & 4.44 & 0.00 & -6.82 \\
\hline No specific reason & 60.37 & 1.91 & 54.11 & 3.78 & 0.00 & -7.95 \\
\hline \multicolumn{7}{|l|}{ Major constraints } \\
\hline Land availability & 0.00 & -3.25 & 0.00 & -10.77 & 87.23 & 14.61 \\
\hline Product flow on the market & 49.05 & 2.20 & 38.43 & 2.04 & 2.12 & -5.78 \\
\hline Climate disturbance & 33.96 & 0.60 & 33.58 & 2.16 & 8.51 & -3.75 \\
\hline Diseases and pests & 16.98 & 1.13 & 27.98 & 3.81 & 2.12 & -4.16 \\
\hline \multicolumn{7}{|l|}{ Sowing method } \\
\hline In bulk & 32.08 & -0.56 & 38.05 & 1.61 & 25.53 & -1.54 \\
\hline In lines & 67.92 & 0.56 & 61.94 & -1.61 & 74.46 & 1.54 \\
\hline \multicolumn{7}{|l|}{ Source of water } \\
\hline Groundwater & 49.05 & 3.25 & 24.25 & -3.42 & 36.17 & 1.08 \\
\hline Rain & 37.73 & 1.61 & 29.10 & 0.57 & 12.76 & 3.56 \\
\hline Catchment & 0.00 & -3.82 & 9.77 & 5.72 & 0.00 & -3.54 \\
\hline Rain and catchment & 13.20 & -2.68 & 26.86 & -0.78 & 51.06 & 3.56 \\
\hline
\end{tabular}


The clustering made it possible to distinguish between three types of market gardening operations. The first type represents $14.40 \%$ of the sample and includes large farms with sizes ranging from 0.50 ha to 1 ha that can be classified as "very little" from an agro-ecological perspective. In fact, pure stand is the sole cropping system adopted by farmers within this first type of market gardening operations $(100 \%)$ (Table 4). This class has not adopted mulching practices $(60.37 \%)$ and the permanent agriculture system $(98.11 \%)$. The fertilisers used are animal dung (32.07\%) and mineral manure (20.75\%). Some producers even prefer not using fertilisers (47.16\%) at all. Soil analysis on the other side has shown that these farms are located on moderately fertile land (50.95\%). Groundwater and rainfall are the main sources of water supply for farms. Some producers have reported adopting pure stand cultivation system for ease of work (39.62\%) whereas others $(60.37 \%)$ did not find any justification for why they choose a different cropping system. The major constraints hindering production are diseases and pests $(16.39 \%)$, access to market (33.96\%) and climatic disturbances $(49.05 \%)$. The presence of diseases and pests imposes a high use of chemicals phytosanitary products $(92.45 \%)$. On these farms, producers have an average appreciation (50.95\%) of the production achieved.

The second class is made of small farms (less than 0.25 ha), representing $72.83 \%$ of the sample (Table 4 ). These types of farms are referred to as "non-agro-ecological". We found that in these farms, sowing is practised in rows $(61.94 \%)$ and farmers presume that production is somehow low $(47.38 \%)$. Mineral fertilisers $(41.41 \%)$ and animal manure $(26.11 \%)$ are the most used types of fertilisers for improving soil fertility. The pure cultivation system is practised because of its ease in carrying out work (45.89\%). Other farmers did not give any reason for choosing this cultivation system $(54.11 \%)$.

The third class also called "agro-ecological", (12.77\% of the total sample) contains small farms (less than 0.25 ha) but unlike the second, most farms within practice crop diversification $(97.32 \%)$, mulching $(80.85 \%)$ and have adopted permanent agriculture system $(68.08 \%)$. Located on less fertile land $(79.59 \%)$, some farmers in this class also use compost $(19.14 \%)$, plant debris $(29.78 \%)$ and animal dung $(10.63 \%)$ as fertilisers, while others do not use fertilisers (31.91\%) (Table 4). As most farmers are land-constrained, intercropping appears to be the recurrent agronomic practice encountered among farmers (40.42\%) as well as crop diversification (59.57\%). As for production self-assessment, most of farmers had reported that their produce is of good quality (55.31\%). Missing markets and access, crop diseases and pests as well as climatic disturbances are not the major production constraints encountered, land availability also stands as a major constraint that hinder productivity market gardening farmers $(87.23 \%)$. The water table at last reports that rainfall and catchment constitute largely $(51.06 \%)$ the main sources of water used by farmers.

\subsection{Analysis of the Determinants of Production Appreciation}

Table 5 presents the determinants of production appreciation.

Table 5. Analysis of the determinants of the appreciation of production by Kabare market gardeners

\begin{tabular}{llll}
\hline Variables & $\chi^{2}$ & DF & Probability \\
\hline Sex & 0.8182 & 1 & $0.36571 \mathrm{~ns}$ \\
Age & 2.6069 & 2 & $0.27158 \mathrm{~ns}$ \\
Education level & 11.8287 & 3 & $0.00799^{* *}$ \\
Market gardening area & 2.4034 & 3 & $0.49299 \mathrm{~ns}$ \\
Main activity & 9.0030 & 2 & $0.01109^{*}$ \\
Type of labour & 23.6159 & 3 & $3.004 \mathrm{e}-05^{* * *}$ \\
Cropping system & 14.4828 & 1 & $0.00014^{* * *}$ \\
Type of fertilisers & 16.4889 & 4 & $0.00242^{* *}$ \\
Mulching & 11.0950 & 1 & $0.00086^{* * *}$ \\
Permanent agricultural system & 4.2812 & 1 & $0.03853^{*}$ \\
Perception of field fertility & 25.1460 & 2 & $3.464 \mathrm{e}-06^{* * *}$ \\
Source of water & 29.8601 & 3 & $1.477 \mathrm{e}-06^{* * *}$ \\
\hline
\end{tabular}

Note. $*=$ significant difference; $* *=$ very significant difference; $* * *=$ very highly significant difference; and ns $=$ non-significant difference at $\alpha=0.05$.

Results reported in Table 5 show that level of education, type of labour force, cropping system, type of fertilisers, mulching practice, practice of the permanent agriculture system, perception of soil fertility and the source of 
water significantly affect the appreciation of market gardeners regarding the level of production achieved $(<$ $0.05)$.

\subsubsection{Separation of Modalities With Significant Determinant Effects}

Modalities with significant determinant effects are presentesd on Table 6.

Table 6. Separation of modalities with significant determinant effects

\begin{tabular}{|c|c|c|c|c|}
\hline Variable & Modality & Coefficient & Standard Error & Group \\
\hline \multirow{4}{*}{ Education level } & Illiterate & 1.714 & 0.843 & $\mathrm{a}$ \\
\hline & Primary school & -1.023 & 0.600 & $\mathrm{a}$ \\
\hline & Secondary school & -0.525 & 0.566 & $\mathrm{ab}$ \\
\hline & University & -2.362 & 1.275 & $a b$ \\
\hline \multirow{4}{*}{ Type of labour } & Family & -1.614 & 0.680 & $\mathrm{a}$ \\
\hline & Family and employee & -1.428 & 0.758 & $\mathrm{a}$ \\
\hline & Community & -0.036 & 0.699 & $a b$ \\
\hline & Employee & 0.882 & 0.581 & $\mathrm{~b}$ \\
\hline \multirow{2}{*}{ Cropping system } & Culture pure & -1.702 & 0.494 & $\mathrm{~b}$ \\
\hline & Polyculture & 0.604 & 0.618 & a \\
\hline \multirow{5}{*}{ Type of fertilisers } & Animal faeces & -1.3111 & 0.539 & $\mathrm{a}$ \\
\hline & Compost & -1.180 & 0.652 & $a b$ \\
\hline & Mineral & -0.551 & 0.525 & $a b$ \\
\hline & None & 0.098 & 0.472 & $\mathrm{~b}$ \\
\hline & Plant debris & 0.199 & 0.688 & $\mathrm{ab}$ \\
\hline \multirow{2}{*}{ Mulching } & Yes & -1.047 & 0.518 & $\mathrm{a}$ \\
\hline & No & -0.050 & 0.452 & $\mathrm{~b}$ \\
\hline \multirow{2}{*}{ Permanent agricultural system } & Yes & -1.018 & 0.542 & $\mathrm{a}$ \\
\hline & No & -0.080 & 0.492 & $\mathrm{~b}$ \\
\hline \multirow{3}{*}{ Perception of field fertility } & High & -3.688 & 1.231 & a \\
\hline & Medium & 0.827 & 0.393 & $\mathrm{~b}$ \\
\hline & Low & 1.213 & 0.431 & $\mathrm{~b}$ \\
\hline \multirow{4}{*}{ Source of water } & Catchment & -0.004 & 0.603 & $\mathrm{a}$ \\
\hline & Rain & -0.031 & 0.509 & $\mathrm{a}$ \\
\hline & Rain and catchment & -0.370 & 0.472 & a \\
\hline & Groundwater & -1.7893 & 0.528 & $\mathrm{~b}$ \\
\hline
\end{tabular}

The results in Table 6 indicate that producers with primary education have a better appreciation of the production compared to other categories. Those with no formal education and those with secondary or university educational level follow them. Farms that employ family labour and hired labour at the same time have good production. They are followed those solely employing hired labour or those making use of community labour only.

Besides, it can be observed that farmers who practise intercropping have a better appreciation of production than those who practise pure stand cropping system. With regard to the type of fertilisers, results showed that farmers who make use of animal manure are able to achieve better production. Those who do not use fertilizer, then those using compost, mineral fertilisers and plant debris follow them. We have also found that the practice of mulching also yields better outcome in terms of production. The same can be said for adoption of permanent agriculture system. It should also be noted in passing that good soil fertility determines good production. Catchment and rainfall as well as catchment and rainfall as a source of water affect more production than the water table.

\subsection{Frequency Distribution of Market Gardening in the Region}

Frequency distribution of gardening items in the region is presented in Table 7. 
Table 7. Frequency distribution of gardening items in the region.

\begin{tabular}{ll}
\hline Crops & Frequency $(\mathbf{N}=\mathbf{3 6 8})$ \\
\hline Cabbage & $13.59(50)$ \\
Onion & $16.85(62)$ \\
Eggplant & $18.48(68)$ \\
Tomato & $13.32(49)$ \\
Pepper & $1.63(6)$ \\
Carrot & $2.72(10)$ \\
Celery & $1.90(7)$ \\
Garlic & $2.45(9)$ \\
Amaranth & $4.35(16)$ \\
Nightshade & $2.17(8)$ \\
Leek & $2.72(10)$ \\
Squash & $3.26(12)$ \\
Bean & $6.79(25)$ \\
Peanut & $4.62(17)$ \\
Pea & $5.16(19)$ \\
\hline
\end{tabular}

The list of market garden crops carried out shows that fifteen (15) crops are grown in the study localities (Table 7). Eggplant is the most dominant (18.48\%) in all the surveyed groupements, followed by onion (16.85\%), cabbage (13.59\%) and tomato (13.32\%). It can also be observed that three legumes are integrated into the market gardening system. These include beans, peas and groundnuts. Legumes are integrated in three ways: either in direct association with certain typical market garden crops, in rotation or in pure stand. In some cases, legumes are found on the farm with market garden crops, but not in direct association. According to information gathered from the focus groups and based on personal observation, some crops are widely grown in some groupements than others. This is the case for onions mostly grown in Mudaka, and tomatoes, cabbage and eggplant widely found in Katana, Bugorhe and Bushwira respectively. On the other hand, in Miti, there is no specific crop. Several crops are grown simultaneously.

\subsection{Frequency Distribution of Vegetable Crop Combinations in the Study Area}

Table 8 shows the frequency distribution of gardening combined items.

Table 8. Frequency distribution of gardening combined items

\begin{tabular}{ll}
\hline Encountered mixing crops & Frequency $\mathbf{( N = 4 7 )}$ \\
\hline Bean-cabbage & $17.02(8)$ \\
Amaranth-Eggplant & $4.26(2)$ \\
Eggplant-Maize & $10.64(5)$ \\
Onion-carrot & $4.26(2)$ \\
Peanut-tomato & $6.38(3)$ \\
Peanut-onion & $21.28(10)$ \\
Amaranth-maize & $8.51(4)$ \\
Tomato-cabbage & $4.26(2)$ \\
Tomato-maize & $8.51(4)$ \\
Amaranth-nightshade-cassava & $4.26(2)$ \\
Tomato-pepper-bean & $4.26(2)$ \\
Chillies-squash-celery-beans & $2.13(1)$ \\
Squash-Pea & $4.26(2)$ \\
\hline
\end{tabular}

Information on the frequency distribution of market gardening associations practised in the region indicates that market gardening is not so frequently practised in association. We observed that out of the 368 market garden producers interviewed, only 47 practice intercropping (Table 8). Among the 13 farming associations listed, amaranth, beans and corn were frequently intercropped. On the other hand, the most common association was peanut and onion $(21.28 \%)$. 


\section{Discussion}

Our results show that the majority of vegetable producers are female, generally married, and are 30 to 50 years old; with a household size of 3 to 7 people. The main activity of the surveyed farmers is market gardening and none of them belongs to any farmer organization. These results reinforce the idea that market gardening is a booming sector in the outskirts of large African cities and where women seem to play a key role, especially for the the development of the sector (Glavana et al., 2018). Market gardening is of greater interest to a certain category of people seeking for employment, food and financial sovereignty. In Benin for example, Nouatin et al. (2010) showed that market gardening production was the main activity and sole source of income for market gardeners. Given the profitability of the activity, young school dropouts are increasingly interested in market gardening and this is in line with the results of Ahouangninou (2013). In order to diversify and secure income, adults no longer hesitate to venture into the sector (Mbah et al., 2013).

Our results indicate that some producers engage in other activities in addition to market gardening due to land constraints but also in order to diversify their activities and sources of income (Lowder et al., 2016). The latter can be petty trade, brick making, handicrafts, logging and other types of gainful occupations in the local environment (Kanda et al., 2006; Mfoukou-Ntsakala et al., 2012).

We observed that market gardeners are classified into three groups according to the criteria used. Dobbs and van Vliet (2015) point out that during typology work, agricultural production units are categorised into various classes. This situation is due to the varied socioeconomic and demographic characteristics of the agricultural actors as well as the technical options that they apply to the farm.

Depending on the mode of access to land, the area farmed and the type of labour, findings showed that vegetable farmers belong to different social classes. Type I farms is mainly made of wealthy farmers, while type II mostly encompasses middle class farmers who are also predominant (72.83\%). Class III is mainly made of poor farmers. Indeed, land is an element of social cohesion, a tool for promoting economic sovereignty. Its mode of acquisition and its extent depend on social organisation and customs applied to a specific place. In Africa for instance, inheritance plays an important role in land acquisition. Most frequently, family first born can inherit family land after the decease of the father or another family member, such as an uncle or an aunt that had chosen him as a legitimate inheritor. In other cases, honest people or more obedient sons can also inherit family land which according to the parent or owner's last wishes become their property and can also be passed on to another generation (Jayne et al., 2014).

In all the surveyed sites, labour is seen as the key performance factor (Veen et al., 2016). This is one of the characteristics of low or non-mechanized agriculture systems. Results had shown that in all the surveyed sites, farmers rely more hired labour, community and family labour due to lack of mechanization. The merits and demerits of each type of labour play a major role in its choice. For instance, the unbearable cost of hired labour usually plays against its choice and favours that of family labour, which turns out to be very cheap. However, farmers with low access to resources and venturing into subsistence agriculture often opt for family labour.

The analysis of the diversity of cropping systems made it possible to identify farms that are "less agro-ecological" and practised on large areas, those that are "non-agro-ecological" and practised on small areas, and finally those that are "agro-ecological" and practised on small areas. It was observed that farms with low agro-ecological and non-agro-ecological production do not obtain higher yields, face lots of market, climatic and phytosanitary (pests and diseases) constraints. On the other hand, agro-ecological farms have good production but are majorly land-constrained.

However, it should be noted that market gardeners work in an environment full of constraints. Aiken (2017) groups most of these constraints in three categories: social, economic and technical, which constitute factors hindering the development of market gardening practice. Nevertheless, Millner (2016), Ferguson and Lovell (2017), and Morel (2016) indicate that the choice of cropping system used in agriculture in general and market gardening in particular is likely to sufficiently mitigate these constraints and/or increase the resilience of the farm in their regard.

However, permaculture, as a method of designing intensive and rational cropping and farming systems based on agro-ecological principles and indigenous knowledge, would be appropriate to address some production constraints in a cost-effective manner (Abigail, 2014). This system will promote important technical orientations, including the possibilities of practicing a permanent agricultural system through the orderly choice of convenient crop successions, thereby promoting farm profitability (Vallaveille et al., 2006). Crop associations based on the practice of crop companionship will reduce phytosanitary pressure, increase crop diversity and secure income (De Olde et al., 2016). These associations will advocate efficient management of solar energy through a good 
densification of the soil vegetation cover, which will constitute a drought mitigation measure (Blignaut et al., 2014). The significant improvement of the level of production appreciation will thus be the results of these various orientations.

Our results indicate that "agro-ecological" farms are characterized by good production. This situation would be because on these farms, producers make use of the major components of agroecology. We observed that they practice crop associations; apply soil moisture conservation practices, which reduce the effects of drought. These results reinforce the conjecture that adoption of permaculture practices would promote the effectiveness of market gardening (Marguerie, 2011). Permaculture advocates agroecology in market gardening in response to the issues of integrated protection, soil restoration and self-fertility, climate change, and land tenure issues in agricultural environments (Francis \& Porter, 2011; Malézieux, 2011). However, the transition to this agro-ecological system would be an effective and inexpensive tool for remedying production constraints. The results obtained indicated that some producers opt for the pure cropping system without specific reasons. This situation is said to be due to a strong attachment to the habits and customs linked to certain technical itineraries (Jerop et al., 2018).

We are seeing the presence of certain legumes such as beans, peas and peanuts in the vegetable farming system. In fact, their presence constitutes a technical and economic opportunity to be effectively exploited as means to improve soil fertility. Their presence also helps ensuring food and financial security, but helps increasing plant biodiversity in market gardening (Stevens, 2015; Justes et al., 2014). We also noted to some extent the presence of beans, amaranth and maize in the listed cropping associations. In fact, considering its very short production cycle, about 21 days, the cultivation of amaranth offers the potential to secure the household both on an economic and nutritional perspective (Nyankanga et al., 2012). Beans are a flagship crop in the region's cropping system, as they are a staple food for the population (Lunze et al., 2012). Maize is mostly associated with tomato in order to mulch the soil with its stubble once dried (Rushigira, 2017).

Among all associations, the peanut-onion association was the most dominant. Litourgidis et al. (2011); Altieri and Petersen (2011) indicated that plant association depends on the mutual interests of the components. The practice depends on the value the producer derives from it. We believe that association of these two crops offer an opportunity for income diversification due to the high demand for both speculations. Moreover, the morphology and spatial arrangement of the two species limit their competition. The ground covered also by peanut helps to maintain moisture for the onion plants. As a legume, it probably also provides nitrogen fertilization for the soil. In addition, phytosanitary problem are not observed in this combination, which is an asset for this plant pair. It is important that research focus on the associations identified in this study in order to establish the scientific attributes for their consolidation. Once these attributes are mastered, these associations can be used as models for agro-ecological packages to be supported in order to make the vegetable cropping system diversified, resilient, sustainable and productive.

\section{Conclusion}

Market gardening is a growing sector in the agricultural production system of South-Kivu. It employs all strata of the population. In view of the food, professional and economic stakes, many find in this sector a reason to satisfy their needs. The results obtained reveal a strong diversity of producers and farms. This diversity is linked with the socio-economic characteristics of market gardeners and definition of technical orientations applied to the farm.

However, the description of the farming system shows that some of its components constitute the constraints that limit its performance. These include the practice of pure cultivation, the non-practice of permanent agriculture, and the non-use of soil moisture conservation practices. Paradoxically, the opposite options of these constraints contribute significantly to the success of the activity. Crop association increases the resilience of the farm to the risk of income loss following the loss of a single crop. It reduces the incidence and severity of diseases and pests. The practice of the permanent farming system ensures regular harvests and therefore frequent income. The application of soil moisture conservation practices reduces the effects of climatic disturbances and contributes to the restoration of soil fertility. Thus, it has been generally observed that the application or adoption of any component of permaculture is effective in contributing to the overall success of market gardening farms.

A practical and participatory understanding of some of the identified agro-ecological components will help to strengthen and clarify their potential for a transition to a sustainable and ecological farming system. 


\section{Acknowledgements}

Authors acknowledge the Université Evangélique en Afrique for manifold support to this study, which was graciously funded through the University project on improvement of research and teaching quality funded by Pain, pour le Monde, Projet A-COD-2018-0383.

\section{References}

Abigail, C. (2014). We are farmers: Agriculture, food security and adaptative capacity among permaculture and conventioneal farmer in Malawi (p. 209, International Abstract Dissertation, American University, District of Columbia).

Ahouangninou, C. (2013). Durabilité de la production maraichère au Sud du Benin: un essai de l'approche systémique (p. 333, Thèse de doctorat, Université d'Abomey Calavi, Benin).

Aiken, G. (2017). Permaculture and the social design of nature. Geografiska Annaler: Series B, Human Geography, 99, 1-20. https://doi.org/10.1080/04353684.2017.1315906

Altieri, M., \& Petersen, P. (2011) Agroecologically efficient agricultural systems for smallholder farmers: contributions to food sovereignty. Agron Sustain Dev, 32, 1-13. https://doi.org/10.1007/s13593-011-0065-6

Balogoun, I., Saidou, A., Ahoton, E. L., Amadji, G., Ahouendo, C. B., Adebo, B., —. Ahanchede, A. (2014). Caractérisation de système de culture d'anacardier dans les principales zones de production du Benin. Agronomie Africaine, 26(1), 9-22.

Birol, E., Slame, M., \& Gyovai, M. (2006). Using a Choice Experiment to Estimate Farmers' Valuation of Agrobiodiversity on Hungarian Small Farms. Environmental \& Resource Economics, 34, 439-469, https://doi.org/10.1007/s10640-006-0009-9

Blignaut, J. N., De Wit, M. P., Knot, J., Midgley, S., Crookes, D. J., Drimie, S., \& Nkambule, N. P. (2014). Sustainable agriculture: A viable option for enhanced food and nutritional security and a sustainable productive resource base in South Africa: An investigation. Baseline Review, Prepared for the Development Bank Southern Africa. Pretoria: ASSET Research.

CIALCA, (2010). CIALCA Baseline Survey Report (p. 129). Consortium for Improving Agriculture-based Livelihoods in Central Africa. IITA, Kampala; TSBF-CIAT, Nairobi; Bioversity Int., Kampala.

Dagnelie P. (1998). Statistique théorique et appliquée. Tome 2: Inférences statistiques à une et deux dimensions (p. 659). De Boeck et Larcier, Paris-Bruxelles, France Belgique.

De Olde E., Oudshoorn F., Bokkers E., Stubsgaard A., Sørensen C., \& De Boer, I. (2016). Assessing the Sustainability Performance of Organic Farms in Denmark. Sustainability, 8, 957. https://doi.org/10.3390/ su8090957

DSCRP, Ministère du Plan RDC. (2011). Rapport macroéconomique et budgétaire. Document de Stratégie de Croissance et de Réduction de la Pauvreté (Vol. 3).

FAO. (2014). Champs écoles sur le manioc: Ressources à l'intention des facilitateurs d'Afrique sub-saharienne (p. 233). Rome, Italy.

Ferguson, R., \& Lovell, S. (2017). Livelihoods and production diversity on U.S. permaculture farms. Agroecology and Sustainable Food Systems, 41, 588-613. https://doi.org/10.1080/21683565.2017.1320349

Francis, C., \& Porter, P. (2011). Ecology in Sustainable Agriculture Practices and Systems. Crit Rev Plant Sci, 30, 64-73. https://doi.org/10.1080/07352689.2011.554353

Glavana, M., Schmutzb, U., Williamsc, S., Corsid, S., Monacod, F., Kneafseye, M., .. Pintar, M. (2018). The economic performance of urban gardening in three European cities-Examples from Ljubljana, Milan and London. Urban Forestry \& Urban Greening, 36, 100-122. https://doi.org/10.1016/j.ufug.2018.10.009

Hothorn, T., Bretz, F., \& Westfall, P. (2008). Simultaneous Inference in General Parametric Models. Biometrical Journal, 50(3), 346-363. https://doi.org/10.1002/bimj.200810425

Imai, K. S., Cheng, W., \& Gaiha, R. (2015). Agricultural Growth, Poverty and Inequality in Developing Countries. Development, 58, 230-236. https://doi.org/10.1057/s41301-016-0009-1

James, W., \& Nlemfu, M. (2016). Agricultural Growth and Investment Options for Poverty Reduction in the DR Congo: A General Equilibrium Approach. J Stock Forex Trad, 5, 168. https://doi.org/10.4172/2168-9458. 1000168 
Jayne, T., Chamberlin, J., \& Headey, D. (2014). Land pressures, the evolution of farming systems, and development strategies in Africa: A synthesis. Food Policies, 48, 1-17, https://doi.org/10.1016/j.foodpol. 2014.05.014

Jerop, R., Dannenberg, P., Owuor, G., Mshenga, P., Kimurto, P., Willkomm, M., \& Hartmann, G. (2018). Factors affectng the adoption of agricultural innovations on underutilized cereals: The case of finger millet among smallholder farmers in Kenya. African Journal of Agricultural Research, 13(36), 1888-1900. https://doi.org/ 10.5897/AJAR2018.13357

Justes, E., Bedoussac, L., Corre-Hellou, G., Fustec, J., Hinsinger, P., Jeuffroy, M. H., ‥ Pelzer, E. (2014). Les processus de complémentarité de niche et de facilitation déterminent le fonctionnement des associations végétales et leur efficacité pour l'acquisition des ressources abiotiques. Innovations Agronomiques, 40, $1-24$.

Karhagomba, B., Ngendakumana, S., Namegabe, M., Mirindi, A., Muhimuzi, B., Bajope, B., \& Isumbisho, M. (2013). Perspectives de gouvernance environnementale durable dans la région de Lwiro (Sud Kivu, République Démocratique du Congo). VertigO (Hors-série 17). https://doi.org/10.4000/vertigo.13826

Lê, S., \& Husson, F. (2008). FactorMiner R: An R Package for Multivariate Analysis, Journal of statistical Software, 25. https://doi.org/10.18637/JSS.v025i01

Litourgidis, A., Dorcos, C., Damolas, A., \& Vlachoslergios, D. (2011). Annual intercrops: An alternative pathway for sustainable agriculture. Australian Journal Crops Science, 396-410.

Lowder, S. K., Skoet, J., \& Raney, T. (2016). The number, size, and distribution of farms, smallholder farms, and family farms worldwide. World Development, 87, 16-29. https://doi.org/10.1016/j.worlddev.2015.10.041

Lunze, L., Mathew, M., Buruchara, R., Michael, A., Nabahungu, L., Gideon, O., ... Idupulapati, R. (2012). In Joan Whalen (Ed.), Integrated Soil Fertility Management in Bean-Based Cropping Systems of Eastern, Central and Southern Africa, Soil Fertility Improvement and Integrated Nutrient Management-A Global Perspective (p. 35). IntechOpen. https://doi.org/10.5772/29151

Malézieux, E. (20112). Designing cropping systems from nature. Agron. Sustain. Dev., 32, 15-29. https://doi.org/ $10.1007 / \mathrm{s} 13593-011-0027$

Mankoussou, M., Mialoundama, F., \& Diamouangana, J. (2016). Évaluation économique de quelques niveaux de fertilisation du maïs (Zea mays L. variété Espoir) dans la Vallée du Niari, République du Congo? Journal of Applied Biosciences, 111, 10894-10904. https://doi.org/104314/jab.v111i1.7

Marguerie, M. (2011). Diversification des cultures dans les exploitations maraîchères biologiques: Conséquences sur les gestions agronomique et commerciale-Cas de la basse vallée de Durance, PACA (p. 78, Mémoire de fin d'étude, Monptelier, SupAgro).

Mbah, L., Havard, M., \& Tempe, L. (2013). Déterminants socio-économiques et institutionnels de l'adoption d'innovations techniques concernant la production du maïs à l'Ouest du Cameroun. Tropiculture, 31(2), 137-142.

Mellor, J. (2014). High rural population density Africa-What are the growth requirements and who participates? Food Policy, 48, 65-75. https://doi.org/10.1016/j.foodpol.2014.03.002

Mfoukou-Ntsakala, A., Bitémo, M., Speybroeck, N., Van Huylenbroeck, G., \& Thys, E. (2012). Agriculture urbaine et subsistance des ménages dans une zone de postconflit en Afrique centrale. Biotechnol. Agron. Soc. Environ., 10 (3), 112.

Millner, N. (2016). Food sovereignty, permaculture and the post-colonial politics of knowledge in El Salvador. Alternative food networks in the postcolonial world. London: Under Contract with Routledge.

MINAGRI. (2013). Plan National d'Investissement Agricole (PNIA), 2014-2020 (p. 108)

Morel, K. (2016). Viabilité des microfermes maraîchères biologiques. Une étude inductive combinant méthodes qualitatives et modélisation (Thèse de doctorat de l'université Paris-Saclay: Préparée a AgroParisTech, école doctorale № 581: Agriculture, Alimentation, Biologie, Environnement et Santé (ABIES) Spécialité de doctorat : Sciences Agronomiques, p. 354).

Ndjadi, S., Basimine, G., Masudi, F., Kyalondawa, M., Mugumaarhama, Y., \& Vwima, S. (2019). Déterminants de la performance des exploitations agricoles à Kabare, Sud-Kivu, Est de la RD Congo. Agronomie Africaine, 31(2), 199-212. 
Nfundiko, C. (2014). La Province du Sud-Kivu peut-elle assurer sa sécurité alimentaire à l’horizon 2050? (p. 187, Mémoire de Master, UEA/Inédit).

Nouatin, G., \& Bachabi, F.-X. (2010). Urbanisation et viabilité de l'activité maraîchère: Cas d'une ville à statut particulier au Bénin (Parakou). VertigO-la revue électronique en sciences de l'environnement (Vol. 10, No. 2). https://doi.org/10.4000/vertigo.10038

Nsimire, A. (2012). De l'exploitation agricole individuelle vers une agriculture entrepreneuriale en milieux ruraux $d u$ Sud-Kivu (Colloque sur "le Genre et agriculture familiale paysanne, Regard Nord-Sud", Le Mirail, Université de Toulouse II).

Nyankanga, R., Onwonga, F., Wekesaet, N., Masinde, D., \& Mugisha, J. (2012). Effect of Inorganic and Organic Fertilisers on the Performance andProfitability of Grain Amaranth (Amaranthus caudatus L.)in Western Kenya. Journal of Agricultural Science, 4(1), 233. https://doi.10.5539/jas.v4n1p223

Ouédraogo, R., Kambiré, F., Kestemont, M., \& Bielders, C. (2019). Caractériser la diversité des exploitations maraîchères de la région de Bobo-Dioulasso au Burkina Faso pour faciliter leur transition agroécologique. Cahiers d'Agricultures, 28, 20. https://doi.org/10.1051/cagri/2019021

Pypers, P., Sanginga, J. M., \& Kasereka, B. (2011). Increased productivity through integrated soil fertility management in cassava-legume intercropping systems in the highlands of Sud-Kivu, DR Congo. Field Crops Research, 120, 76-85. https://doi.org/10.1016/j.fcr.2010.09.004

R Core Team. (2018). R: A Language and environment for statistical computing. R Foundation for Statistical Computing, Vienna.

Rushigira, C. (2017). Analyse technico-économique de la production maraichère à Kamanyola dans la Plaine de la Ruzizi/RDC: Contraintes et stratégies d'acteurs (p. 129, Mémoire de Master de Spécialisation en Développement, Environnement et Sociétés, UCL, ESPO).

Stevens, C. (2015). Permaculture et maraichage biologique: Un choix économique intéressant? Baricade et culture alternatives (p. 40).

USAID. (2015). Assessment of the DRC'S agricultural market systems: Value chains in the Nord and South-Kivu and Katanga Provinces. Leo Report 16 (p. 199).

Van Vliet, J. A., Schut, A. G. T., Reidsma, P., Descheemaeker, K., Slingerland, M., van de Ven, G. W. J., \& Giller, K. (2015). De-mystifying family farming: Features, diversity and trends across the globe. Global Food Security, 5, 11-18. https://doi.org/10.1016/j.gfs.2015.03.001

Vanlauwe, B., Descheemaeker, K., Giller, K., Huising, J., Merckx, R., Nziguheba, G., Wendt, J., \& Zingore, S. (2015). Integrated soil fertility management in sub-Saharan Africa: unravelling local adaptation. Soil, 1, 491-508. https://doi.org/10.5194/soil-1-491-2015

Veen, E., Bock, B., Van den Berg, W., Visser, A., \& Wiskerke, J. (2016). Community gardening and social cohesion: Different designs, different motivations. Local Environ., 21, 1271-1287. https://doi.org/10.1080/ 13549839.2015.1101433

Venables, W., \& Ripley, B. (2002). Modern Applied Statistics with S (4th ed.). Springer, New York, NY. https://doi.org/10.1007/978-0-387-21706-2

Vwima, S., Mastaki, J.-L., \& Lebailly, P. (2013). Le rôle du commerce frontalier des produits alimentaires avec le Rwanda dans l'approvisionnement des ménages de la ville de Bukavu (Province du Sud-Kivu). Les Cahiers de l'Association Tiers Monde (p. 28).

\section{Copyrights}

Copyright for this article is retained by the author(s), with first publication rights granted to the journal.

This is an open-access article distributed under the terms and conditions of the Creative Commons Attribution license (http://creativecommons.org/licenses/by/4.0/). 